\title{
New record of fresh-water green algae (Chlorophytes) from Korea
}

\author{
Han Soon Kim* \\ Department of Biology, Kyungpook National University, Daegu 702-701, Korea
}

\begin{abstract}
The present study summarized the occurrence, distribution and autecology about 31 taxa of the green algae (Chlorophytes) collected from several swamps, reservoir and highland wet-lands in the South Korea from 2010 to 2013 . This paper deals with a total 31 taxa including of 26 genera which are recorded for the first time in Korea. Among these algae, 18 genera including Pyrobotrys Arnoldi, Volvulina Playfair, Dicellula Svirenko, Echinocoleum Jao \& Lee, Hofmania Chodat, Gloeotila Kützing, Tetrachlorella Korschikov, Botryospherella P.C.Silva etc., were newly recorded in Korean fresh-water algal flora.
\end{abstract}

Key words: Chlorophytes, Korean fresh-water algal flora, newly recorded

\section{INTRODUCTION}

Since Kawamura (1918) reported a species of Centritractus at lake Seoho, Suwon, about 1,800 taxa of freshwater algae, excluding diatoms, have been recorded in Korea (Chung 1968, Chung 1970, 1975, 1976, 1979, 1993, Chung et al. 1972a, 1972b, Chung and Lee 1986, Chung and Kim 1992, 1993, Wui and Kim 1987a, 1987b, Kim 1992, 1996, Kim and Chung 1993, 1994, Kim et al. 2009), and about 1,100 taxa of Chlorophytes have been recorded in Korea. Although about 1,100 taxa of Chlorophytes have been recorded in Korea, as a similar number to those recorded from the UK (about 1,100 species, John et al. 2011) and Japan (about 1,500 species, Hirose and Akiyama 1977) only $13.7 \%$ of the 8,000 worldwide species of Chlorophytes have been reported in Korea (Van den Hoek et al. 1995). The most floristic or taxonomic studies of Chlorophytes from Korea were investigated along with other taxonomic groups of freshwater algae.

Recently, the importance of biological diversity has been increasing emphasized, and the discovery of indigenous species as biological resources is recognized as an urgent national task. Therefore, the investigation of fresh-water algae within regions of Korea, including unusual environments (e.g., highland moorlands, mountain sphagnum bogs or wet-lands and crater) is immediately required.

More than 500 samples were collected from various water bodies throughout the country were investigated for establishment fresh-water algal flora in Korea. In the present study, 18 genera and 31 species of Chlorophytes are reported for the first time in Korea.

\section{MATERIALS AND METHODS}

Over 500 samples were collected from various types of wetland habitats including eutrophic reservoirs, diverse swamps to oligotrophic and acidic mountainous wetl-ands, sphagnum bogs, orum (very small and shallow caldera lakes) from 2009 to 2013 (Fig. 1 and Table 1). The samples were obtained by means of plankton net (mesh size $25 \mu \mathrm{m}$ ), spoid or by squeezing submerged macrophytes and living materials were immediately examined. http://dx.doi.org/10.5141/ecoenv.2013.303

(c) $\$$ This is an Open Access article distributed under the terms of
the Creative Commons Attribution Non-Commercial Licens
(http://creativecommons.org/licenses/by-nc/3.0/) which
permits unrestricted non-commercial use, distribution, and reproduction in any
medium, provided the original work is properly cited.
Received 29 October 2013, Accepted 18 November 2013

*Corresponding Author

E-mail: kimhsu@knu.ac.kr

Tel: +82-53-950-5344 


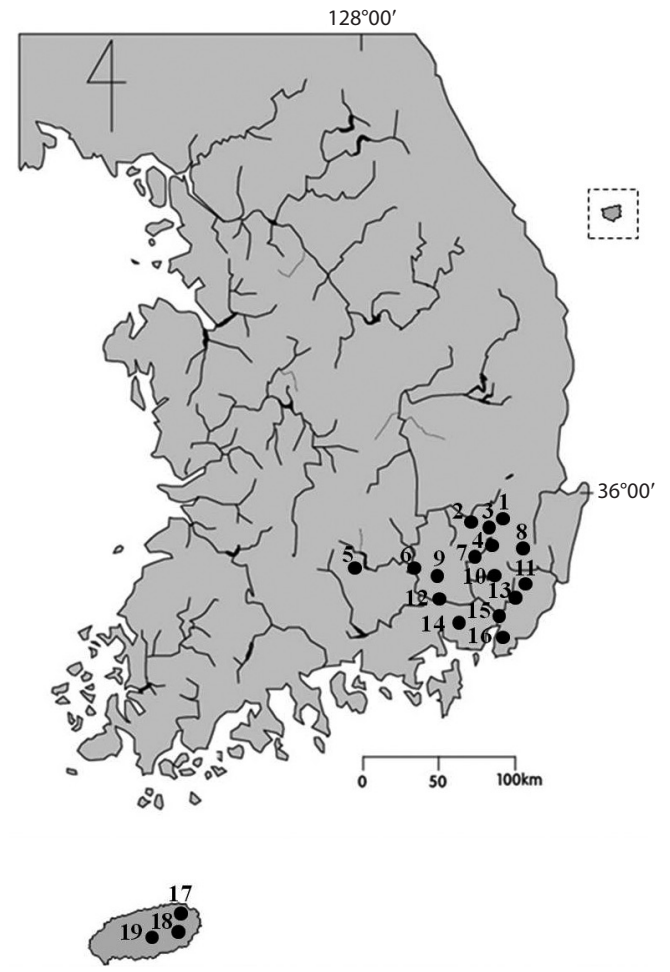

Fig. 1. Location of sampling sites in the territory of Korea. Numbers on the map represent as follow: 1, Guryong reservoir; 2, Otong reservoir; 3, Sayang reservoir; 4, Unmoon lake; 5, Mochje; 6, Geokpo bridge; 7, Imdang weir; 8 , Okbang wet-lands; 9, Jangcheok reservoir; 10, Danjang stream; 11, Mujechineup; 12, Namji great bridge; 13, Sinbulsanneup; 14, Junam reservoir; 15, Yangsan great bridger; 16, Samlak wet-lands; 17, Dongbaekdongsan; 18, Micheongul; 19, Mulyoungari. See detailed information of sampling site in Table 1.

After first examination living materials, they were preserved in Lugol's solution for permanent preservation and detail identification. Microscopic examinations were made at $\times 200$ to $\times 1,000$ magnification using an Axio Imager microsope (A2; Carl Zeiss, Oberkochen, Germany) and photographs were taken with an AxioCam HRC camera (Carl Zeiss). Water temperature, $\mathrm{pH}$, and conductivity were measured in the field by means of a HI8314 membrane pH meter (Hanna instruments, Smithfield, RI, USA) and a HI9835 EC meter (Hanna instruments). A total of 31 species of Chlorophyta which had not previously been recorded from Korea are depicted with photographs and briefly discussed with regard to their ecology and distribution in Korea. Genus which had not previously been recorded from Korean fresh-water algal flora was marked with an asterisk $\left(^{*}\right)$. The materials are deposited at the National Institute of Biological Resources (NIBR) and Department of Biology, Kyungpook National University. Following abbreviations are used: (Basion.) Basionym; (Syn.) Synonym; (Dist.) distribution; (rr) very rare; (r) occasional; (c) abundant; (cc) very abundant.

\section{RESULTS AND DISCUSSION}

\section{Class Chlorophyceae \\ Order Volvocales \\ Family Spondylomoraceae}

${ }^{*}$ Pyrobotrys casinoensis (Playfair) Silva 1938 (Fig. 2A and 2B)

References: Yamagishi and Akiyama 1987b, p 52; John et al. 2011, p 405, pl. 102, fig. B.

Description: Colonies mulberry shaped, composed of 8 or 16 cells; cells ovoid to pear-shaped, with a stigma and two contractile vacuoles; two flagella at the anterior end of the cell; posterior cells tiers often protruding the posterior ends; chloroplasts single, cup-shaped, without pyrenoids; cells 18-21 $\mu \mathrm{m}$ long, colonies up to $60 \mu \mathrm{m}$ long.

This species usually occurs in organically enriched shallow reservoir and swamps, and is distributed worldwide.

Dist.: 16 (Dist. numbers indicate sampling site in Fig. 1 and Table 1) (17 Jul 2011; r).

Pyrobotrys squarrosa (Korshikov) Korshikov 1938 (Fig. 2C)

Reference: Yamagishi and Akiyama 1987a, p 62.

Description: Colonies star-shaped, consisting of 8 cells; cells irregularly pear-shaped with a strongly inflated, ventral side and a long posterior tail with a somewhat blunted end; two flagella situated on the anterior dorsal side, more or less apart from the anterior end of the cell; chloroplasts single, cup-shaped, without pyrenoids; cells 22-24 $\mu \mathrm{m}$ long, $10 \mu \mathrm{m}$ in diameter; colonies up to $35 \mu \mathrm{m}$ long.

This species usually occurs in organically enriched shallow reservoir and swamps, and distributed worldwide.

Dist.: 16 (17 Jul 2011; rr).

\section{Family Volvocaceae}

*Volvulina steinii Playfair 1915 (Fig. 2D and 2E)

References: Yamagishi and Akiyama 1995a, p 72; John et al. 2011, p 405, pl. 102, fig. D.

Description: Colony spherical to ellipsoidal, up to 60 $\mu \mathrm{m}$ in diameter, usually with 16 cells $10-20 \mu \mathrm{m}$ in diameter; cells lenticular to hemispherical, with two equal flagella and many contractile vacuoles on the surface; chloroplast single, cup-shaped, absent pyrenoid in young cultures, but usually developing a single in old cultures; anterior part of cell with stigma. This species is similar to Eudorina and Pandorina, but it distinguished from the 
letters by its flattened and almost hemispherical cells.

This species distributed worldwide, and it rarely occurs in mesotrophic shallow reservoirs, ponds and temporary puddles, often associated with other volvocales.

Dist.: 5 (12 Aug 2010; rr), 14 (17 Jul 2011; rr), 19 (12 Aug 2010; rr).

\section{Order Tetrasporales Family Palmellopsidaceae}

\section{*Asterococcus superbus (Cienkowski) Scherffel 1908 (Fig. 2F and 2G)}

Syn.: Chlamydomonas scherffeli Korshikov 1917.

References: Yamagishi and Akiyama 1997b, p 6; John et al. 2011, p 376, pl. 96, fig. B.

Description: Cells spherical to ellipsoidal, solitary or in 2, 4, 8 celled colonies, with a broad lamellate and mucilaginous envelope, individual cell envelope conspicuous; cell wall smooth; chloroplasts a single, stellate with several rays flattened against the cell wall, with a central pyrenoid; cells 20-25 $\mu \mathrm{m}$ in diameter.

This species is distributed worldwide, and it frequently occurs associated with marginal vegetation in nutrient poor shallow reservoir, ponds and bog pools as well as organically enriched temporary puddles and shallow ponds.

Dist.: 5 (12 Aug 2010; r), 8 (9 Sep 2012; r), 19 (12 Aug 2010; r).
*Gloeodendron ramosum Korschikov 1916 (Fig. 4C and 4D)

Syn.: Prasadiella indica Srivastava 1978.

Reference: Yamagishi and Akiyama 1997b, p 31.

Description: Thalli simple or di-to tetrachotomously branched in dendroid, gelatinous, cylindrical strand, containing cells sparsely arranged singly or in pair, sometimes in colony, along the whole length, attached to the substratum; gelatinous strands unequal in width and compact transversely layered, cross-lamellations, between the cell or cell colony, and concentrically layered surrounding the cells; cells ovoid to globose; chloroplasts single, cup-like, with a pyrenoid; cells 5-10 $\mu \mathrm{m}$ in diameter; strands with a single row of the cell 20-25 $\mu \mathrm{m}$ in diameter.

This species distributed worldwide, and it rarely occurs associated with marginal vegetation in nutrient poor shallow waters.

Dist.: 19 (12 Aug 2010; r).

\section{Family Tetrasporaceae}

*Paulschulzia pseudovolvox (P. Schultz) Skuja 1948 (Fig. 2H)

Basion.: Tetraspora pseudovolvox P. Schultz 1923.

Syn.: Tetraspora nygaardii Teiling.

Reference: John et al. 2011, p. 377, pl. 96, fig. D.

Description: Colonies spherical or broadly ellipsoid,

Table 1. Informations of smapling sites

\begin{tabular}{|c|c|c|c|c|c|}
\hline No. & Sampling location & Characteristic of Sampling site & pH & EC & Alt. \\
\hline 1 & $128^{\circ} 58^{\prime} 05^{\prime \prime} \mathrm{E}, 35^{\circ} 49^{\prime} 55^{\prime \prime} \mathrm{N}$ & Shallow mesotrophic reservoir & $6.5-7.8$ & $90-150$ & 560 \\
\hline 2 & $128^{\circ} 53^{\prime} 20^{\prime \prime} \mathrm{E}, 35^{\circ} 52^{\prime} 30^{\prime \prime} \mathrm{N}$ & Shallow mesotrophic reservoir & $7.6-8.2$ & $85-110$ & 120 \\
\hline 3 & $128^{\circ} 53^{\prime} 00^{\prime \prime} \mathrm{E}, 35^{\circ} 46^{\prime} 30^{\prime \prime} \mathrm{N}$ & Shallow mesotrophic reservoir & 7.3-8.5 & $95-130$ & 140 \\
\hline 4 & $128^{\circ} 56^{\prime} 00^{\prime \prime} \mathrm{E}, 35^{\circ} 44^{\prime} 30^{\prime \prime} \mathrm{N}$ & Oligo to mesotrophic artificial lake & $6.6-8.7$ & $65-120$ & 160 \\
\hline 5 & $128^{\circ} 12^{\prime} 40^{\prime \prime} \mathrm{E}, 35^{\circ} 34^{\prime} 10^{\prime \prime} \mathrm{N}$ & Oligotrophic natural mountain shallow small pond & $6.6-7.7$ & $65-96$ & 180 \\
\hline 6 & $128^{\circ} 21^{\prime} 50^{\prime \prime} \mathrm{E}, 35^{\circ} 31^{\prime} 30^{\prime \prime} \mathrm{N}$ & Middle-lower part of Nakdong river, mesotrophic water & $6.8-7.5$ & $40-105$ & 20 \\
\hline 7 & $128^{\circ} 55^{\prime} 00^{\prime \prime} \mathrm{E}, 35^{\circ} 42^{\prime} 25^{\prime \prime} \mathrm{N}$ & Dongchang stream, oligo to mesotrophic water & $6.7-7.5$ & $45-110$ & 40 \\
\hline 8 & $129^{\circ} 05^{\prime} 05^{\prime \prime} \mathrm{E}, 35^{\circ} 46^{\prime} 20^{\prime \prime} \mathrm{N}$ & Abandoned paddy field wet-lands & $6.2-7.5$ & $27-45$ & 480 \\
\hline 9 & $128^{\circ} 29^{\prime} 05^{\prime \prime} \mathrm{E}, 35^{\circ} 26^{\prime} 10^{\prime \prime} \mathrm{N}$ & Old shallow mesotrophic reservoir & $7.2-8.3$ & $103-155$ & 30 \\
\hline 10 & $128^{\circ} 55^{\prime} 30^{\prime \prime} \mathrm{E}, 35^{\circ} 29^{\prime} 40^{\prime \prime} \mathrm{N}$ & Oligotrphic river water & $6.8-7.5$ & $40-105$ & 40 \\
\hline 11 & $129^{\circ} 08^{\prime} 30^{\prime \prime} \mathrm{E}, 35^{\circ} 27^{\prime} 50^{\prime \prime} \mathrm{N}$ & Oligotrophic mountainous Sphagnum bog & $5.5-7.0$ & $25-35$ & 650 \\
\hline 12 & $128^{\circ} 32^{\prime} 30^{\prime \prime} \mathrm{E}, 35^{\circ} 23^{\prime} 20^{\prime \prime} \mathrm{N}$ & Mesotrophic puddle water & $6.8-7.7$ & $56-90$ & 20 \\
\hline 13 & $128^{\circ} 59^{\prime} 30^{\prime \prime} \mathrm{E}, 35^{\circ} 25^{\prime} 20^{\prime \prime} \mathrm{N}$ & Oligotrophic Sphagnum bog & $5.5-6.2$ & $15-30$ & 700 \\
\hline 14 & $128^{\circ} 39^{\prime} 50^{\prime \prime} \mathrm{E}, 35^{\circ} 18^{\prime} 35^{\prime \prime} \mathrm{N}$ & Old shallow mesotrophic reservoir & $6.8-7.5$ & $160-197$ & 20 \\
\hline 15 & $129^{\circ} 00^{\prime} 00^{\prime \prime} \mathrm{E}, 35^{\circ} 17^{\prime} 05^{\prime \prime} \mathrm{N}$ & Lower part of Nakdong river, mesotrophic water & $7.1-8.5$ & 115-205 & 5 \\
\hline 16 & $128^{\circ} 58^{\prime} 20^{\prime \prime} \mathrm{E}, 35^{\circ} 10^{\prime} 40^{\prime \prime} \mathrm{N}$ & Mesotrophic artificial wet-lands & $6.7-7.5$ & $44-121$ & 5 \\
\hline 17 & $126^{\circ} 44^{\prime} 10^{\prime \prime} \mathrm{E}, 33^{\circ} 31^{\prime} 06^{\prime \prime} \mathrm{N}$ & Samll oligotrophic rock pond & $6.1-7.5$ & $44-57$ & 30 \\
\hline 18 & $126^{\circ} 50^{\prime} 18^{\prime \prime} \mathrm{E}, 33^{\circ} 23^{\prime} 05^{\prime \prime} \mathrm{N}$ & Small, shallow olitrophic wet-land & $6.1-7.0$ & $28-40$ & 40 \\
\hline 19 & $126^{\circ} 41^{\prime} 20^{\prime \prime} \mathrm{E}, 33^{\circ} 22^{\prime} 50^{\prime \prime} \mathrm{N}$ & Oligotrophic crater & $5.6-7.0$ & $36-55$ & 150 \\
\hline
\end{tabular}

EC: electronical conductivity, Alt.: Altitude. 
with $2,4,8,16,32,64$ or more cells, $40-350 \mu \mathrm{m}$ in diameter, large colonies with subgroups of 2-6 cells surrounded by an inner mucilage investment; cells spherical, 6-13 $\mu \mathrm{m}$ in diameter, thin-walled, with 2 pseudocilia up to $200 \mu \mathrm{m}$ long and often extending beyond the mucilage envelope; chloroplast cup-shaped, sometimes with eyespot.
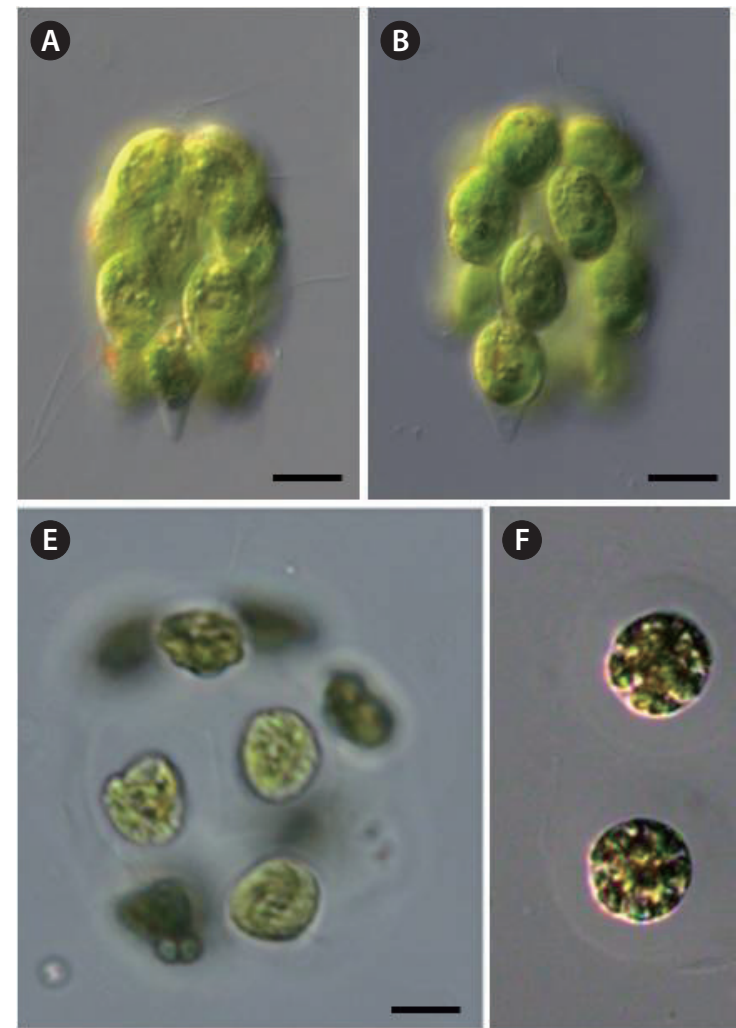

F

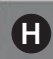

H
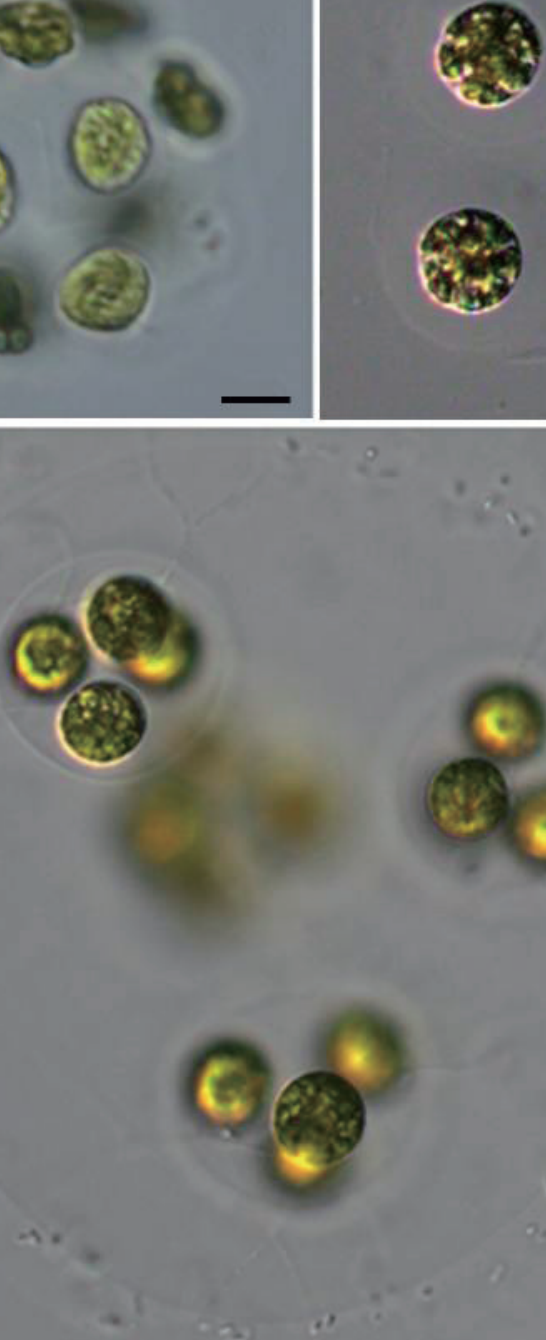

C
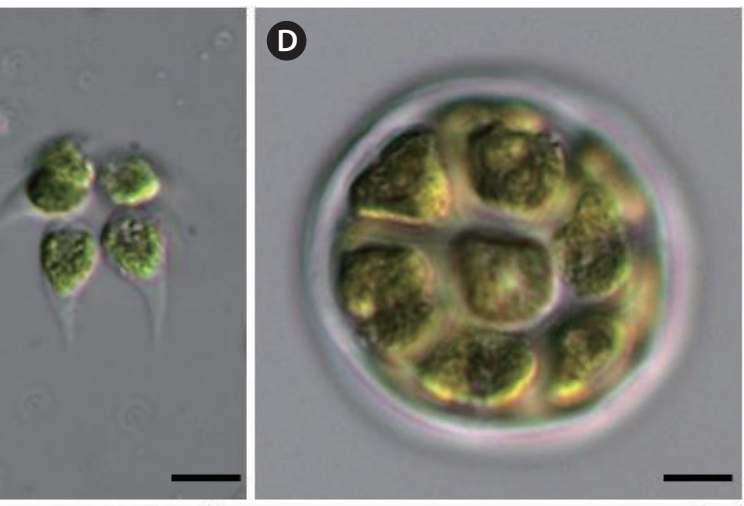

G
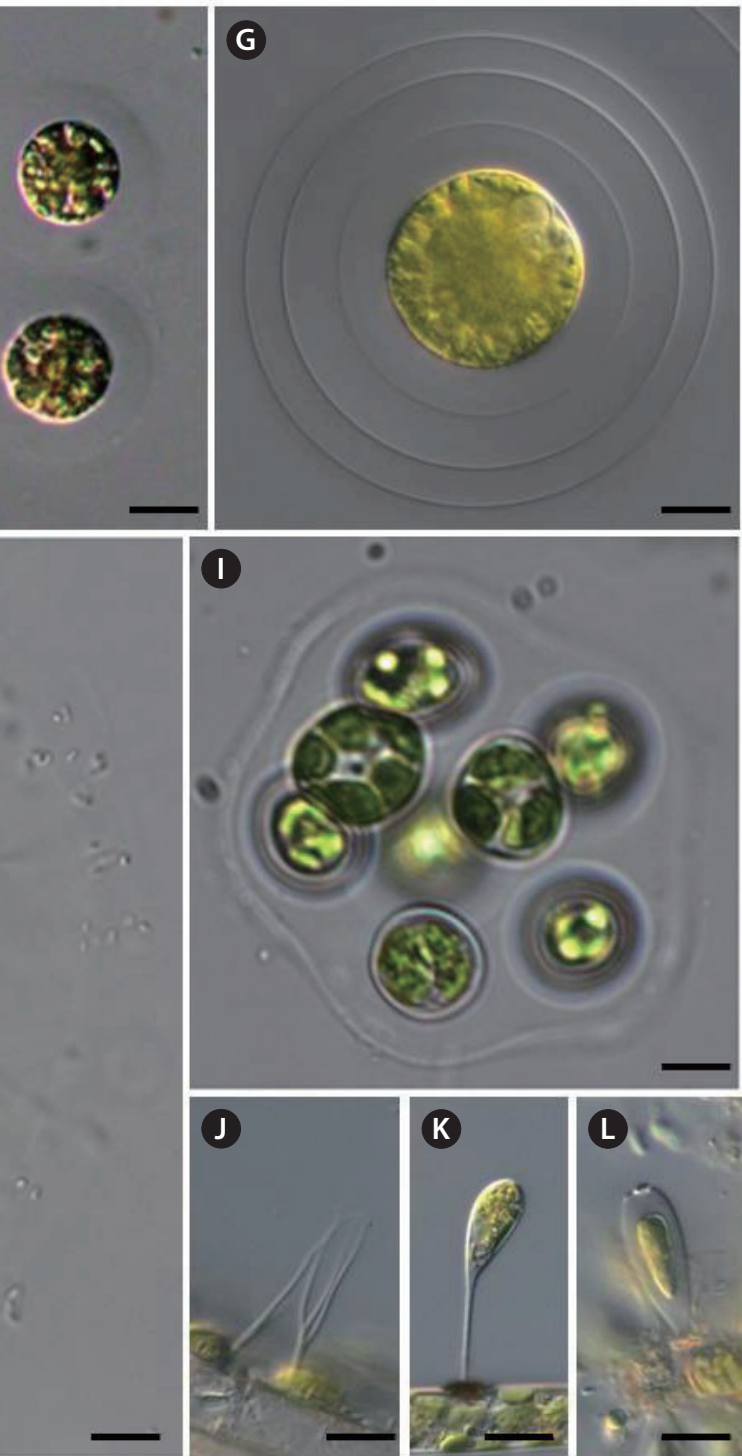

Fig. 2. (A, B) Pyrobotrys crasinoensis, (C) P. squarrosa, (D, E) Volvulina steinii, (F, G) Asterococcus superbus, (H) Paulschulzia pseudovolvox, (I) Planktosphaeria gelatinosa, (J) Dicranochaete reniformis, (K) Characium guttula, (L) Pseudocharacium obtusum. Scale bars, $10 \mu \mathrm{m}$. 
This species reported in Europe, Australia and New Zealand. Rarely occurs as plankton in oligotrophic to mesotrophic lakes, reservoirs and ponds and is often associated with marginal aquatic vegetation.

Dist.: 8 (9 Sep 2012; r), 18 (11 Aug 2010; r).

\section{${ }^{*}$ Gloeochaete wittrockiana Lagerheim 1883 (Fig. 3F)}

Syn.: Gloeochaete bicornis Kirchner 1888.

References: Yamagishi and Akiyama 1985, p 47; John et al. 2011, p 767, pl. 96, fig. M.

Description: Colonies epiphytic upon the other filamentous algae, solitary or 2, 4, 8 celled; cells spherical, embedded within a broad hyaline mucilagenous envelope; each cells with 1-3 long, erect gelatinous setae; cells with ovoid or sausage-shaped cyanelles, lying close together in a cup-shaped region; cells 6-21 $\mu \mathrm{m}$ in diameter, setae $100-250 \mu \mathrm{m}$ long.

This species distributed worldwide, and it rarely occurs associated with marginal vegetation in the nutrient poor shallow waters.

Dist.: 19 (12 Aug 2010; r).

\section{Order Chlorococcales Family Chlorellaceae}

*Elakatothrix genevensis (Reverdin) Hindák 1962 (Fig. 3A and 3B)

Basion.: Ankistroodesmus genevensis Reverdin 1919.

Reference: Yamagishi and Akiyama 1995b, p 35.

Description: Colonies 4, 8, 16 cells, rarely 2 cells or more, enclosed by a fusiform, mucilaginous envelope, free-floating; cells elongated fusiform to slightly asymmetric fusiform, narrowed into the pointed ends, slightly detached each other side by side in the colonial envelope; chloroplasts single, parietal, laminate, with 1-2 pyrenoid; cells $3-4 \mu \mathrm{m}$ in diameter, $13-20 \mu \mathrm{m}$ long.

This species distributed worldwide, and it usually occurs as planktonic in shallow mesotrophic reservoirs and pond in summer.

Dist.: 2 (4 Jun 2013; r).

\section{Quadrigulla closteroides (Bohkin) Printz 1916 (Fig. 5K)}

Basion.: Nephrocytium closteroides Bohlin.

Syn.: Ankistrodesmus closteroides (Bohlin) Printz.

References: Komárek and Fott 1983, p 680, pl. 190, fig.

3; Yamagishi and Akiyama 1987b, p 53; John et al. 2011, p 467, pl. 116, fig. B.

Description: Colonies comprised of 4-8-16 or more detached cells, enclosed with a hyaline mucilaginous envelope; cells long-cylindrical or fusiform and parallel in sheath, slightly lunate or arcuate in lateral view, tapering to subacute ends, arranged in longitudinal bundles of 4 cells in the colonial envelope; chloroplasts single, parietal plate-like, with a single pyrenoid; cells $2.5-4 \mu \mathrm{m}$ in diameter, 20-30 $\mu \mathrm{m}$ long.

This species distributed worldwide, and it usually occurs as planktonic in shallow mesotrophic reservoirs and ponds in summer.

Dist.: 8 (11 Aug 2011; r).

\section{Family Palmellaceae}

*Planktosphaeria gelatinosa G.M. Smith 1918 (Fig. 2I)

References: Komárek and Fott 1983, p 100, pl. 25, fig. 1; Yamagishi and Akiyama 1984a, p 72; John et al. 2011, p 465, pl. 107, fig. M.

Description: Cells solitary, or more commonly in colonies of $8,16,32$ cells, compactly grouped or irregularly distributed in a spherical, homogeneous, hyaline mucilaginous envelope; cells spherical; chloroplasts single, cup-shaped in young cells, several parietal, angular discoid in mature cells, with a pyrenoid; cells $10-25 \mu \mathrm{m}$ in diameter, colony up to $250 \mu \mathrm{m}$ in diameter.

This species distributed worldwide, and it usually occurs as planktonic in reservoirs and pond in summer.

Dist.: 7 (15 Apr 2010; r).

\section{Family Dicranochaetaceae}

*Dicranochaete reniformis LHieronymus 1890 (Fig. 2J)

Syn.: Dicranochaete reniformis var. laevis Hodgetts.

References: Yamagishi and Akiyama 1984a, p 40; John et al. 2011, p 566, pl. 135, fig. J.

Description: Cells solitary, epiphytic, hemispherical in the side view and reniform in vertical view; enclosed by a thick, gelatinous sheath; branched, gelatinous setae arising from the base or dorsal side of the sheath; chloroplasts single, cup-shaped with 2-3 pyrenoid; cells 18-24 $\mu \mathrm{m}$ in diameter, setae $35 \mu \mathrm{m}$ long.

This species probably cosmopolitan, and rarely occurs as an epiphyte on submerged plants and larger filamentous algae in acidic Sphagnum bog.

Dist.: 13 (27 Apr 2013; r).

\section{Family Characiaceae}

\section{Characium guttula Playfair (Fig. 2K)}

References: Komárek and Fott 1983, p 204, pl. 59, fig. 3; Yamagishi and Akiyama 1997a, p 19.

Description: Cells solitary, epiphytic, narrow ovoid, 



Fig. 3. (A, B) Elakatothrix genevensis, (C-E) Gloeotaenium loitelsbergianum, (F) Gloeochaete wittrockiana, (G) Coenococcus planktonicus, (H) Botryosphaerella sudetica, (I) Echinocoleum elegans. Scale bars, $10 \mu \mathrm{m}$.

apices broadly rounded, posterior end conically narrowed towards the base, with a thin, long straight stalk having a small basal disk; chloroplasts a single, curved parietal laminate, with a pyrenoid; cells $5-10 \mu \mathrm{m}$ in diameter, 14-16 $\mu \mathrm{m}$ long without stalk, stak length 16-20 $\mu \mathrm{m}$ long.

This species reported in Portugal, Romania, Spain, Australia and New Zealand, and it rarely occurs in swamp, small shallow reservoirs and ponds.

Dist.: 13 (27 Apr 2013; r).

\section{*Pseudocharacium obtusum (A. Braun) Perty-Hesse} 1968 (Fig. 2L)

Syn.: Characium obtusum Matvienko.

References: Komárek and Fott 1983, p 190, pl. 55, fig. 3; Yamagishi and Akiyama 1988, p 5; John et al. 2011, p 466, pl. 106, fig. M.

Description: Cells solitary, epiphytic, elongate ellipsoid to narrow ovoid, apical end broadly rounded, obtuse, with a ring-like wall thickening, thick walled; sessile or with very short stalk; single chloroplasts ageing cells with one 
to several pyrenoid; cells 5-10 $\mu \mathrm{m}$ in diameter, $20-25 \mu \mathrm{m}$ long.

This species is probably cosmopolitan, and rarely occurs on submerged surface in swamp, small shallow reservoirs and ponds.

Dist.: 1 (26 Apr 2013; r).

\section{Family Treubariaceae}

\section{Treubaria quadrispina (G.M. Smith) Fott \& Kovácik 1975} (Fig. 5I)

Basion.: Polyedriopsis quadrispina G.M. Smith.

References: Komárek and Fott 1983, p 267, pl. 79, fig. 4; Yamagishi and Akiyama 1989b, p 99.

Description: Colonies free-floating, solitary, compressed rectangular in front view, side straight or convex, corners generally rectangular and with a slightly rounded apex; each corner with a single, stout, straight spine; spines broad at the base, gradually attenuated to an acute point, lying in a plane; chloroplasts cup-shaped and filing most of the cell, with a pyrenoid; cells $6-8.5 \mu \mathrm{m}$ in diameter, spines 17-22 $\mu \mathrm{m}$ long.

This species distributed worldwide, and it usually occurs as planktonic in shallow mesotrophic reservoirs and ponds in summer.

Dist.: 12 (11 Aug 2011; c).

\section{Treubaria setigera (W.Archer) G.M. Smith 1933 (Fig. 5J)}

Basion.: Tetrapedia setigera W. Archer.

References: Komárek and Fott 1983, p 267, pl. 79, figs. 2, 3; Yamagishi and Akiyama 1993, p 92; John et al. 2011, p 418, pl. 121, fig. M.

Description: Cells solitary, free-floating, distinctly triangular, with sides slightly concave and broadly rounded apices bearing 3 narrow, spine-like appendages lying in a single plane, hyaline spine tapered to an acute point; chloroplasts single, with one pyrenoid; cells 9-11 $\mu \mathrm{m}$ in diameter, spines 15-22 $\mu \mathrm{m}$ long.

This species distributed worldwide, and it usually occurs as planktonic in shallow mesotrophic reservoirs and ponds in summer.

Dist.: 12 (11 Aug 2011; c).

\section{Family Micractiniaceae}

\footnotetext{
*Dicellula geminata (Printz) Korshikov 1953 (Fig. 4I)

Basion.: Franceia geminata Printz 1914.

Syn.: Dicellula planctonica Swirenko; Franceia tuberculata G.M. Smith.

References: Komárek and Fott 1983, p 337, pl. 102, fig.
}

2; Yamagishi and Akiyama 1988, p 37; John et al. 2011, p 480, pl. 118, fig. I.

Description: Colonies free-floating, 2-celled, rarely 4 or more celled; cells parallel, attached with their long lateral sides; cells ovoid to ellipsoid; wall smooth and covered with many long, straight, fine spines; each spine with extended thickened base; chloroplasts usually two, parietal laminate, each with a pyrenoid; cells $8.5-10 \mu \mathrm{m}$ in diameter, 18-20 $\mu \mathrm{m}$ long, spines 15-20 $\mu \mathrm{m}$ long.

This species is probably cosmopolitan, rarely occurring in planktonic form or associated with submerged plants in lakes, reservoirs and ponds.

Dist.: 6 (24 Jul 2011; rr).

\section{Family Botryococcaceae}

\section{*Botryosphaerella sudetica (Lemmermann) P.C. Silva 1970 (Fig. 3H)}

Syn.: Botryococcus sudetica Lemmermann.

References: Komárek and Fott 1983, p 374, pl. 112, fig. 1; Yamagishi and Akiyama 1984b, p 5; John et al. 2011, p 411, pl. 107, fig. A.

Description: Colonies free-floating, irregular shaped, formed by several globose or ovoid, botryoidal small cell clusters, connected with broad, gelatinous strands, yellow-green to green in color; cells spherical to subspherical, radiately arranged around a common center in each botryoidal cluster; clusters composed of $4,8,16,32$, or more cells; inner base of cells connected by hyaline gelatinous strands, outer end without the sheath; chloroplasts single, cup-shaped to discoid, without pyrenoid; cells $6-12 \mu \mathrm{m}$ in diameter.

This species is distributed worldwide, and usually occurs in peat-bogs or with Sphagnum in littoral of oligotrophic to dystrophic pools and small reservoirs, sometimes in great abundance. Botryosphaerella very similar to Botryococcus but distinguished in that cells not being embedded in special mucilaginous envelope and by the absence of pyrenoids.

Dist.: 11 (22 Sep 2012; c), 13 (27 Apr 2013, 2 Jun 2013; c), 19 (12 Sep 2009; c).

\section{Family Radiococcaceae}

\section{*Coenococcus planctonicus Korshikov 1953 (Fig. 3G)}

Syn.: Eutetramorus planktonicus (Korshikov) Bourrelly.

References: Komárek and Fott 1983, p 300, pl. 88, fig. 3; John et al. 2011, p 434, pl. 107, fig. C.

Description: Coenobia 4, 8, 16 or 32 cells and cells forming dense tetrads lying within a spherical gelati- 
nous envelope; cells spherical, $8-11 \mu \mathrm{m}$ in diameter, wall smooth; chloroplast cup-shaped, with a single pyrenoid; autospores $(-2) 4(-8)$ in each sporangium.

This species is probably cosmopolitan, usually occurring in planktonic form or associated with submerged aquatic plants in various oligotrophic to eutrophic aquatic habitats such as swamp, shallow reservoir and ponds.

Dist.: 18 (13 May 2010; r).

\section{*Pectodictyon pyramidale Akiyama \& Hirose 1962 (Fig.} $4 \mathrm{~K})$

References: Komárek and Fott 1983, p 436, pl. 132, fig. 1; Yamagishi and Akiyama 1994, p 37.

Description: Coenobia of 4, 8, rarely 26 celled, freefloating; cells pyramidately arranged in 4-celled coenobia, cubically in 8-celled and polygonally in 16-celled ones; cells triangular pyramidal, triangular in lateral view, with one truncate process outwardly protruded and two inner truncate processes, two slightly concave outer sides and one roundly swelled inner side, covered with a thick, hyaline wall, and connected to each other by elongation of the three inner corners of the cell; chloroplast single, parietal, with a pyrenoid; cells $8-14 \mu \mathrm{m}$ in diameter with process.

This species has been reported in Japan and China and is rarely occurs as planktonic form of reservoir and ponds.

Dist.: 5 (4 Jun 2012; rr).

\section{Palmodictyon viride Kützing 1845 (Fig. 4A and 4B)}

References: Komárek and Fott 1983, p 442, pl. 133, fig. 2; John et al. 2011, p 460, pl. 106, fig. Q.

Description: Cells spherical, 8-11 $\mu \mathrm{m}$ in diameter, solitary or in groups of 2 or 4 , surrounded with a simple or branched tubular, gelatinous envelope; single chloroplast per cell, cup-shaped, with a single pyrenoid.

This species is probably cosmopolitan, and usually occurs associated with submerged aquatic plants in swamp, shallow reservoir and ponds.

Dist.: 8 (9 Sep 2012; r), 10 (5 Aug 2010; r).

\section{Family Oocystaceae}

\section{${ }^{*}$ Echinocoleum elegans Jao \& Lee 1947 (Fig. 3I)}

References: Komárek and Fott 1983, p 491, pl. 145, fig. 1; Yamagishi and Akiyama 1987a, p 35.

Description: Cells solitary, ellipsoid, free-floating; cells enclosed by hyaline, gelatinous sheath bearing 8-10 horn-like processes; chloroplasts a single, parietal laminate with a pyrenoid; cells $3-4 \mu \mathrm{m}$ broad, $4-6 \mu \mathrm{m}$ long.

This species has been recorded in China and Japan, is very rarely occurs in planktonic or associated with submerged aquatic plants in reservoir and ponds.

Dist.: 5 (22 Jun 2012; rr).

${ }^{*}$ Gloeotaenium loitelsbergerianum Hansgirg 1890 (Fig. 3C-3E)

References: Komárek and Fott 1983, p 525, pl. 154, fig. 1; Yamagishi and Akiyama 1985, p 48; John et al. 2011, p 483, pl. 107, fig. P.

Description: Colony usually $2-4$ celled, cells retained within the persistent mother cell wall, cells of the 2 or 4-celled colonies lying in the same plane or tetrahedrally arranged; 4 cells encircled by one or more dark-brown, usually appearing X-shaped, gelatinous bands; cells oval to spherical, separated within the colony from each other by the dark colored bands; cell wall thick, lamellated; chloroplasts single, massive, usually with a single pyrenoid but indistinct in adult cell; cells $15-30 \mu \mathrm{m}$ in diameter, colony up to $55 \mu \mathrm{m}$ in diameter.

This species is probably cosmopolitan, and usually rarely occurs associated with submerged aquatic plants in swamp, shallow reservoir and ponds.

Dist.: 2 (10 Aug 2013; rr).

\section{Family Coelastraceae}

\section{Coelastrum indicum W.B. Turner 1892 (Fig. 4E and 4F)}

References: Komárek and Fott 1983, p 737, pl. 205, fig. 5.

Description: Colony free-floating, spherical, 4, 8, 16 or 32 celled, with intercellular spaces of hexagonal or rounded; cells angular, connected to neighboring cells by 5-6 truncated short processes, but each cell without any process on the outer face of the cells; cells 11-12 $\mu \mathrm{m}$ in diameter.

This species is probably cosmopolitan, and usually occurs in planktonic or associated with submerged aquatic plants in lakes, reservoir and ponds.

Dist.: 17 (12 Aug 2010; c).

\section{Coelastrum pulchrum Schmidle 1892 (Fig. 4G)}

Syn.: Coelastrum cambricum W. Archer 1868.

References: Komárek and Fott 1983, p 736, pl. 205, fig. 2; John et al. 2011, p 431, pl. 108, fig. L.

Description: Colony spherical comprised of 4, 8, 16 or 32 celled; cells spherical, enclosed by a delicate gelatinous sheaths with 5 to 6 short, stout, truncate processes radiating from marginal portion, single process toward the outer face of the cell; cells connected to adjacent ones by the marginal stout processes; intercellular spaces triangular or rounded; cells 15-20 $\mu \mathrm{m}$ in diameter. 


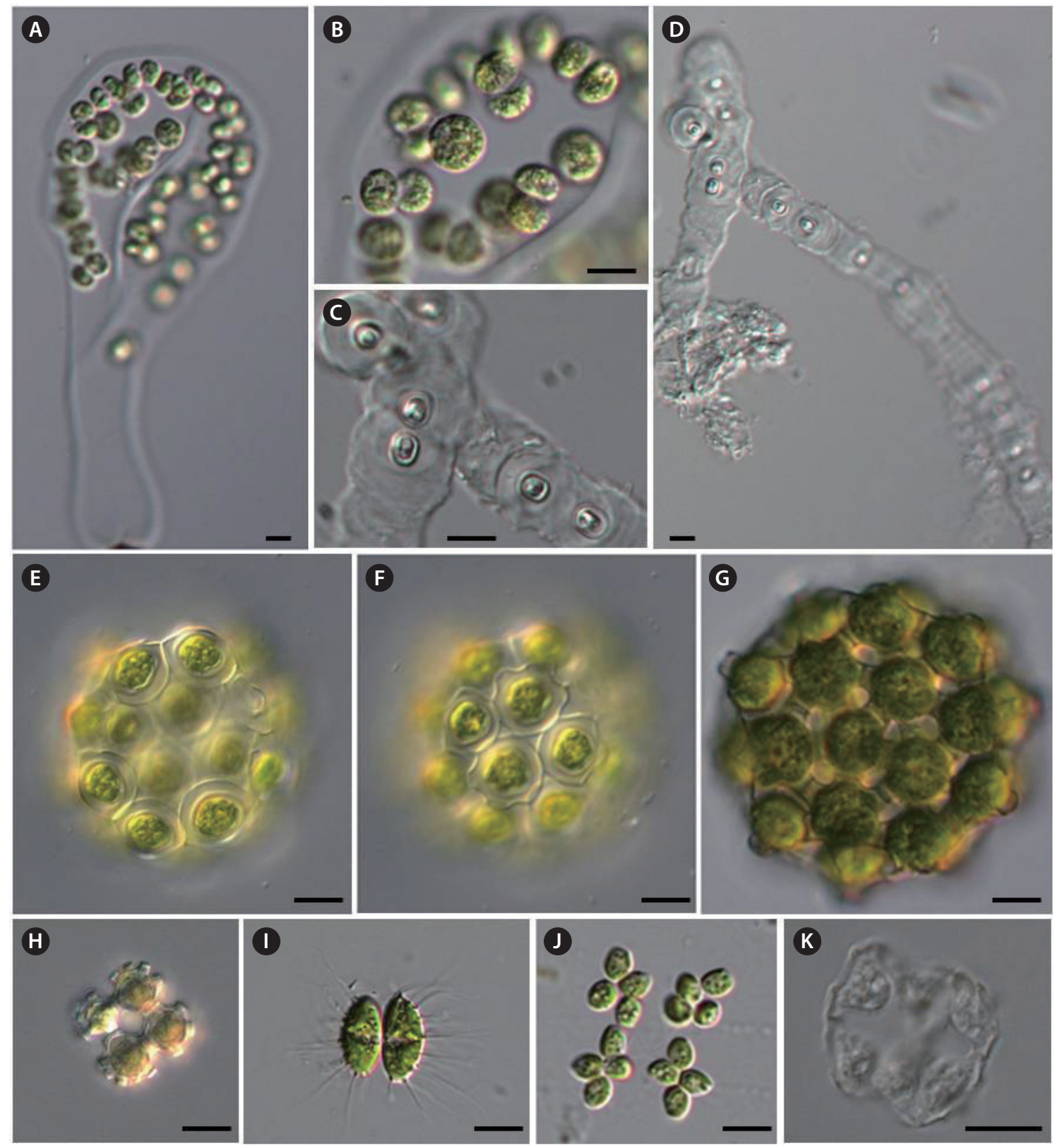

Fig. 4. (A, B) Palmodictyon viride, (C, D) Gloeodendron ramosum, (E, F) Coelastrum indicum, (G) C. pulchrum, (H) C. verrucosum, (I) Dicellula geminata, (J) Hofmania africana, (K) Pectodictyon pyramidale. Scale bars, $10 \mu \mathrm{m}$.

This species is probably cosmopolitan, and usually occurs in planktonic or associated with submerged aquatic plants in reservoirs and ponds.

Dist.: 17 (12 Aug 2010; c).

\section{Coelastrum verrucosum (Reinsch) Reinsch 1892 (Fig.4H)}

Syn.: Coelastrum morus W \& G.S. West 1896.

References: Komárek and Fott 1983, p 732, pl. 204, fig. 2; Yamagishi and Akiyama 1986, p 16.
Description: Colony spherical comprised of $4,8,16$ or 32 celled; cells spherical, enclosed by a delicate gelatinous sheaths with 4 to 10 small truncate, wart-like processes on outer face of the cell; cells connected to adjacent ones by the basal stout processes; cells 9-12 $\mu \mathrm{m}$ in diameter.

This species is probably cosmopolitan, and rare occurring in planktonic form or associated with submerged aquatic plants in reservoirs and ponds.

Dist.: 7 (13 May 2010; r). 

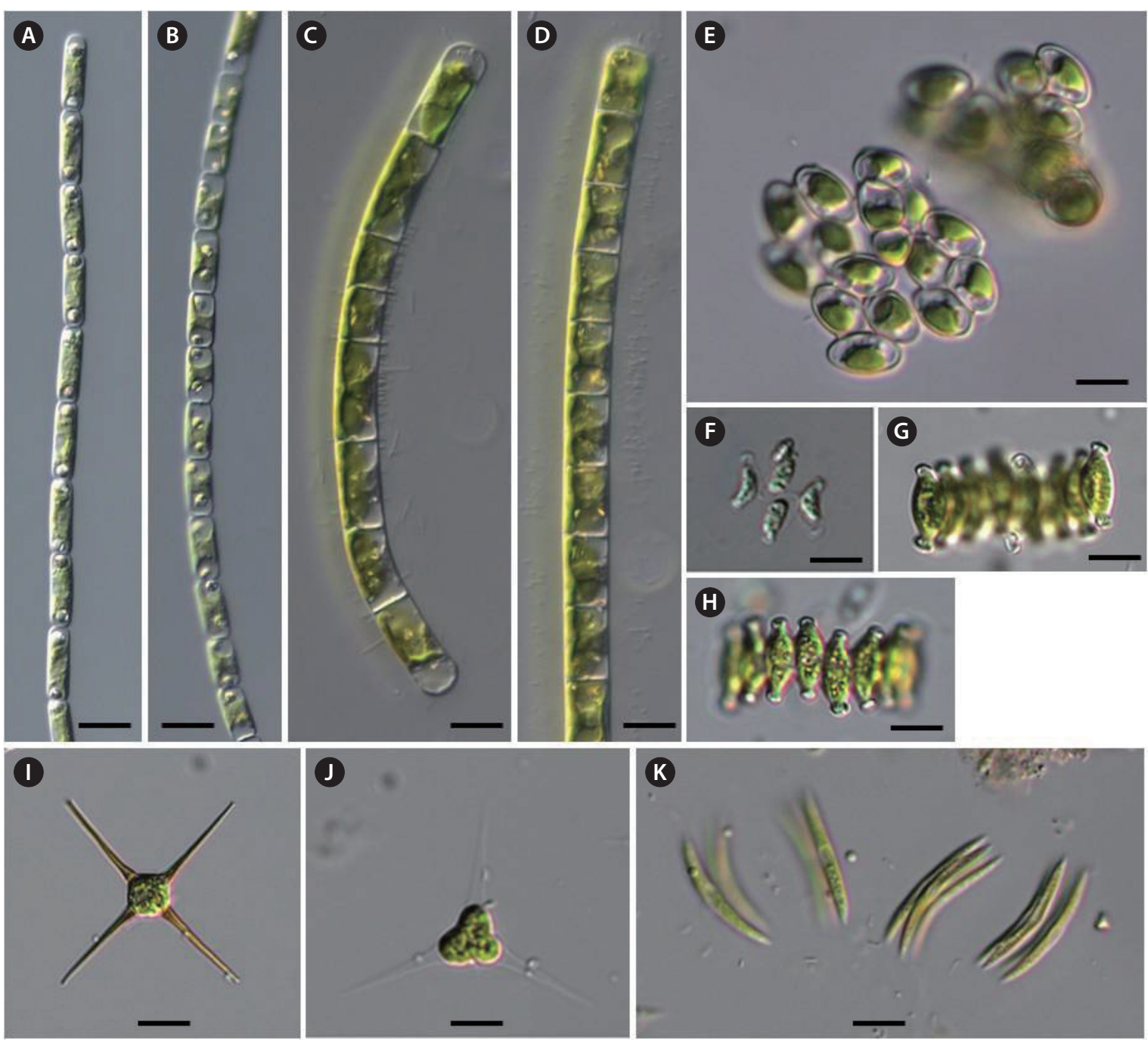

Fig. 5. (A, B) Gloeotila pulchra, (C, D) Gloeotilopsis planktonica, (E) Tetrachlorella alternans, (F) Scenedesmus indicus, (G, H) S. product-capitatus, (I) Treubaria quadrispina, (J) T. setigera, (K) Quadrigula closterioides. Scale bars, $10 \mu \mathrm{m}$.

\section{Family Scenedesmaceae}

\section{*Tetrachlorella alternans (G.M. Smith) Korschikov 1939} (Fig. 5E)

Syn.: Crucigenia alternans G.M. Smith 1926; Scenedesmus arcuatus var. irregularis E.A. Flint.

References: Komárek and Fott 1983, p 762, pl. 212, fig. 3; Yamagishi and Akiyama 1989a, p 84; John et al. 2011, p 498, pl. 109, fig. H.

Description: Coenobia free-floating, flat, 4 cells, sometimes 16 celled syncoenobium, with hyaline, mucilaginous envelope; cells long, ellipsoid, with broadly rounded or bluntly pointed apices, grouped in pairs or 4 cells, alternately, densely disposed in mutual contact at the center and without a central open space; cell wall smooth; chloroplasts a single, parietal laminate with or without a pyrenoid; cells $6-9 \mu \mathrm{m}$ broad, $10-14 \mu \mathrm{m}$ long.

This species has been recorded in China and Japan, is very rare and occurs in planktonic form or associated with submerged aquatic plants in reservoir and ponds.

Dist.: 15 (5 Aug 2010; rr).

\section{*Hofmania africana Woloszynska 1914 (Fig. 4J)}

References: Yamagishi and Akiyama 1997b, p 32; John et al. 2011, p 460, pl. 106, fig. Q.

Description: Coenobia flat, cross- to wreath-shaped, consisting of 4 cells, usually 16 cells enclosed within a hyaline gelatinous envelope; cells ovoid with a narrowly acute outer end and broadly rounded basal end, 4 cells grouped cruciately and radiately connecting with swelled 
dish-like old mother cell wall remnant by the basal end; chloroplast a single, parietal, with a single pyrenoid; cells 4-5 $\mu \mathrm{m}$ in diameter, 5-9 $\mu \mathrm{m}$ long.

This species is probably cosmopolitan, and very rare occurring in planktonic form or associated with submerged aquatic plants in reservoirs and ponds.

Dist.: 12 (11 Aug 2011; r).

\section{Scenedesmus indicus Philipose 1967 (Fig. 5F)}

Syn.: Scenedesmus product-capitatus var. indicus (Philipose) Hegewald 1976.

References: Komarek and Fott 1983, p 833, pl. 226, fig. 9; Hegewald and Silva 1988, p 271, fig. 441; Yamagishi and Akiyama 1995a, p 54.

Description: Colonies 4 celled; cells fusiform to broad fusiform, curved lunate, capped at both ends of the outer cells and only outer end of the inner cells, and middle part swollen, contacting outer ends of internal cells and the middle part of the outer cells alternately, internal cells contact with each other at the end part; cell wall smooth; cells $3-5 \mu \mathrm{m}$ broad, 9-12 $\mu \mathrm{m}$ long.

This species is probably cosmopolitan, and rare, occurring in planktonic form or associated with submerged aquatic plants in lakes, reservoir and ponds.

Dist.: 19 (12 Sep 2009; r).

\section{Scenedesmus producto-capitatus Schmula 1910 (Fig. 5G} and $5 \mathrm{H}$ )

References: Komárek and Fott 1983, p 833, pl. 227, fig. 1; Hegewald and Silva 1988, p 405, fig. 651; Yamagishi and Akiyama 1995a, p 55.

Description: Colonies 2, 4, or 8 celled; cells fusiform to broad fusiform, with a tubercular swelling, sometimes visible like two small tubercles at both ends, contacting part of the sides in a linear series; cell wall smooth; cells 5-7 $\mu \mathrm{m}$ in diameter, $15-18 \mu \mathrm{m}$ long.

This species is probably cosmopolitan, and rare, occurring in planktonic form or associated with submerged aquatic plants in lakes, reservoir and ponds.

Dist.: 1 (6 Jun 2013; c), 12 (11 Aug 2011; c), 16 (11 Aug $2011 ; \mathrm{r})$.

\section{Order Ulotrichales Family Ulotrichaceae}

\section{${ }^{*}$ Gloeotila pulchra Skuja 1948 (Fig. 5A and 5B)}

References: Yamagishi and Akiyama 1994, p 20.

Description: Filaments free-floating, short, unbranched, uniseriate, straight or slightly curved, contacting with each other at the round ends; chloroplasts a single, pa- rietal laminate, nearly filing the entire cell, without pyrenoid; some granules seen inside the vacuole at the end of the cell; cells $4.5-6 \mu \mathrm{m}$ broad, $8-15 \mu \mathrm{m}$ long.

This species has been reported from Australia, New Zealand and Japan, and rarely occurs in planktonic form in reservoir and ponds.

Dist.: 1 (6 Jun 2013; c).

${ }^{*}$ Gloeotilopsis planctonica Iyengar \& Philipose 1956 (Fig. 5C and 5D)

References: Yamagishi and Akiyama 1994, p 21; Hu and Wei 2006, p 679, pl. 14-37, figs. 3-5.

Description: Filaments short, $2-16$ celled, unbranched, uniseriate, without mucilaginous sheath, free-floating; cells elongated cylindrical, terminal cells with rounded end; chloroplasts single, parietal, long plate-like, occupying almost entire cell length, with 1-2 pyrenoids; cells 10 $\mu \mathrm{m}$ broad, 14-16 $\mu \mathrm{m}$ long.

This species has been reported in Spain, India, China and Japan, and rarely occurs in planktonic in reservoir and ponds or terrestrial.

Dist.: 9 (12 Aug 2011; c).

\section{CONCLUSION}

In this study, a total 18 genera and 31 species of Chlorophytes reported for the first time in fresh-water algal flora of Korea.

\section{ACKNOWLEDGMENTS}

This work was supported by a grant from the National Institute of Biological Resources (NIBR), funded by the Ministry of Environment (MOE) of the Republic of Korea (NBIR No. 2013-01-001).

\section{LITERATURE CITED}

Chung J. 1970. A taxonomic study on the Fresh-water algae from Youngnam area. PhD Dissertation, Kyungpook National University, Daegu, Korea. (in Korean)

Chung J. 1975. A study on the Euglenophyceae from Chon La Book Do area. Res Rev Kyungpook Natl Univ 20: 233242. (in Korean with English abstract)

Chung J. 1976. A study on the Cyanophyceae from Chun Ra Book Do area. Kor J Bot 19: 19-30. (in Korean with English abstract) 
Chung J. 1979. A study on the Fresh-water algae from Chungchong Book Do area. Korean J Limnol 12: 41-53. (in Korean with English abstract)

Chung J. 1993. Illustrations of the Korean freshwater algae. Academy, Seoul. (in Korean)

Chung J, Kim HS. 1992. Fresh-water algae new to Korea (II). Kor J Phycol 7: 173-183. (in Korean with English abstract)

Chung J, Kim HS. 1993. Fresh-water algae new to Korea (III). Kor J Phycol 8: 37-46. (in Korean with English abstract)

Chung J, Kim SD, Lee KS. 1972a. Fresh-water algae from Jeju Ju Do Island (I). Korean J Limnol 5(1): 13-23. (in Korean with English abstract)

Chung J, Kim SD, Lee KS. 1972b. Fresh-water algae from Jeju Ju Do Island (II). Korean J Limnol 5(3): 15-31. (in Korean with English abstract)

Chung YH. 1968. Illustratied Encylopedia of Fauan and Flora of Korea. Vol. 9, Fresh Water Algae. Samwha Publishing, Seoul. (in Korean)

Chung YH, Lee OM. 1986. A taxonomic study of desmids on several lowland swamps in Haman. Proc Coll Nat Sci Seoul Natl Univ 11: 51-98. (in Korean with English abstract)

Hegewald E, Silva PC. 1988. Annotated catalogue of Scenedesmus and nomenclaturally related genera, including original descriptions and figures. Bibl Phycol 80: 1-587.

Hu HJ, Wei YX. 2006. The freshwater algae of China. Systematics, Taxonomiy and Ecology. Science Publish, Beijing. (in Chinese)

John DM, Whitton BA, Brook AJ. 2011. The freshwater algal flora of the British Isles. 2nd ed. Cambridge University Press, Cambridge.

Kawamura T. 1918. Freshwater biology of Japan. 1st ed. Shokabo, Tokyo. (in Japanese)

Kim HS. 1992. Taxonomic and Ecological studies of freshwater algae on natural swamps and reservoirs at Changnyong County Area. PhD Dissertation. Kyungpook National University, Daegu, Korea. (in Korean with English abstract)

Kim HS. 1996. Desmids (Staurastrum and Staurodesmus) from Kyongsangnam-Do, Korea. Nova Hedwigia 62: 521-541.

Kim HS, Chung J. 1993. Freshwater algal flora of natural swamps in Chnagnyong County. Korean J Limnol 26: 305-319. (in Korean with English abstract)

Kim HS, Chung J. 1994. Fresh-water algae new to Korea (IV). Kor J Phycol 9: 1-6.
Kim JH, Park YJ, Kim HS. 2009. Silica-scaled chrysophytes (Synurophyceae) from Jeju Island, Korea. Nova Hedwigia 89: 201-218.

Komárek J, Fott B. 1983. Chlorophyceae (Grunalgen) Ordnung: Chlorococcales. In: Das Phytoplankton des Süßwassers. Die Binnengewässer XVI, 7(1) (HuberPestalozzi G, ed). Schweiz Verg, Stuttgart.

Van den Hoek C, Mann DG, Jahns HM. 1995. Algae: An introduction to phycology. Cambridge University Press, Cambridge.

Wui IS, Kim BH. 1987a. The Flora of the Fresh-Water Algae in Chol La Nam Do, Korea (I) Euglenophyceae. Kor J Phycol 2: 119-127. (in Korean with English abstract)

Wui IS, Kim BH. 1987b. Flora of the Fresh-Water Algae in Chol La Nam Do, Korea (II) Cyanophyceae. Kor J Phycol 2: 193-201. (in Korean with English abstract)

Yamagishi T, Akiyama M. 1984a. Photomicrographs of the Fresh-water algae. Vol. 1. Uchida Rokakuho, Tokyo.

Yamagishi T, Akiyama M. 1984b. Photomicrographs of the Fresh-water algae. Vol. 2. Uchida Rokakuho, Tokyo.

Yamagishi T, Akiyama M. 1985. Photomicrographs of the Fresh-water algae. Vol. 3. Uchida Rokakuho, Tokyo.

Yamagishi T, Akiyama M. 1986. Photomicrographs of the Fresh-water algae. Vol. 5. Uchida Rokakuho, Tokyo.

Yamagishi T, Akiyama M. 1987a. Photomicrographs of the Fresh-water algae. Vol. 6. Uchida Rokakuho, Tokyo.

Yamagishi T, Akiyama M. 1987b. Photomicrographs of the Fresh-water algae. Vol. 7. Uchida Rokakuho, Tokyo.

Yamagishi T, Akiyama M. 1988. Photomicrographs of the Fresh-water algae. Vol. 8. Uchida Rokakuho, Tokyo.

Yamagishi T, Akiyama M. 1989a. Photomicrographs of the Fresh-water algae. Vol. 9. Uchida Rokakuho, Tokyo.

Yamagishi T, Akiyama M. 1989b. Photomicrographs of the Fresh-water algae. Vol. 10. Uchida Rokakuho, Tokyo.

Yamagishi T, Akiyama M. 1993. Photomicrographs of the Fresh-water algae. Vol. 11. Uchida Rokakuho, Tokyo.

Yamagishi T, Akiyama M. 1994. Photomicrographs of the Fresh-water algae. Vol. 13. Uchida Rokakuho, Tokyo.

Yamagishi T, Akiyama M. 1995a. Photomicrographs of the Fresh-water algae. Vol. 14. Uchida Rokakuho, Tokyo.

Yamagishi T, Akiyama M. 1995b. Photomicrographs of the Fresh-water algae. Vol. 15. Uchida Rokakuho, Tokyo.

Yamagishi T, Akiyama M. 1997a. Photomicrographs of the Fresh-water algae. Vol. 18. Uchida Rokakuho, Tokyo.

Yamagishi T, Akiyama M. 1997b. Photomicrographs of the Fresh-water algae. Vol. 19. Uchida Rokakuho, Tokyo. 